\title{
THE "LATINS" ON MANGUP. UNIQUE WESTERN-EUROPEAN CROSS-ENCOLPION FROM THE EXCAVATIONS OF PRINCE'S PALACE IN ANCIENT MANGUP: PROBLEMS OF ATTRIBUTION AND DATING ${ }^{1}$
}

\author{
Valery E. Naumenko \\ V.I. Vernadsky Crimean Federal University, Simferopol, Russian Federation
}

\begin{abstract}
Introduction. The article is devoted to the analysis of a unique cross-encolpion of the WesternEuropean type from the excavations of the Mangup Prince's Palace. Methods. The research is complex. When describing the find, traditional methods of art history analysis were used, and data from X-ray fluorescence studies were used to determine the material of the product. Attribution of the cross is made on the basis of the generally accepted method of analogies in archaeological science. Analysis. The encolpion is related to a small group of cast silver crosses with "Latin" features, which were produced during the third quarter of the $15^{\text {th }}$ century in one of the craft workshops of Kaffa. Their author was a master-scholarship holder who most likely moved to the capital of Genoese Gazaria in the Northern Black Sea region from one of the cities of Northern Italy. Results. Among the many reasons why this encolpion, as a mandatory attribute of the clothing of a Catholic Priest, could end up on Mangup, the most likely are: unknown in the sources Genoese embassy to the capital of the Principality of Feodoro in the period of 1450-1475 for the purpose of establishing a permanent Catholic mission here; the presence of a Catholic priest in the large embassies of Kaffa to the court of the rulers of Feodoro in 1455, 1465 or around 1471; participation of Genoese, who fled from Kaffa after its capture by the Ottoman army, in the subsequent defense of the Mangup fortress in summer and autumn 1475.
\end{abstract}

Key words: Mangup fortress, Byzantium, Feodoro principality, Genoese Gazaria, palace, encolpion.

Citation. Naumenko V.E. The "Latins" on Mangup. Unique Western-European Cross-Encolpion from the Excavations of Prince's Palace in Ancient Mangup: Problems of Attribution and Dating. Vestnik Volgogradskogo gosudarstvennogo universiteta. Seriya 4. Istoriya. Regionovedenie. Mezhdunarodnye otnosheniya [Science Journal of Volgograd State University. History. Area Studies. International Relations], 2020, vol. 25, no. 6, pp. 100-115. (in Russian). DOI: https://doi.org/10.15688/jvolsu4.2020.6.7

\section{«ЛАТИНЯНЕ» НА МАНГУПЕ. \\ УНИКАЛЬНЫЙ ЗАПАДНОЕВРОПЕЙСКИЙ КРЕСТ-ЭНКОЛПИОН ИЗ РАСКОПОК КНЯЖЕСКОГО ДВОРЦА МАНГУПСКОГО ГОРОДИЩА: ПРОБЛЕМЫ АТРИБУЦИИ И ДАТИРОВКИ ${ }^{1}$}

\author{
Валерий Евгеньевич Науменко \\ Крымский федеральный университет им. В.И. Вернадского, г. Симферополь, Российская Федерация
}

Аннотация. Статья посвящена анализу уникального креста-энколпиона западноевропейского типа из раскопок Мангупского княжеского дворца, который не имеет аналогов за многие годы исследований памятников поздневизантийского Крыма. Всестороннее изучение находки позволяет соотнести ее с небольшой группой нательных литых серебряных крестов с «латинскими» чертами, которые, очевидно, выпускались в 
течение третьей четверти XV в. в одной из ремесленных мастерских Каффы. Их автором являлся мастерстипендиарий, скорее всего переселившийся в столицу Генуэзской Газарии из Северной Италии. Среди множества причин, по которым энколпион как обязательный атрибут одежды католического священнослужителя мог оказаться на Мангупе, наиболее вероятными представляются следующие: неизвестное в источниках генуэзское посольство в столицу православного княжества Феодоро в период 1450-1475 гг. с целью учреждения здесь постоянной католической миссии (прихода, монастыря); присутствие католического священника в составе крупных посольств Каффы ко двору правителей Феодоро в 1455, 1465 или около 1471 гг.; участие генуэзцев, бежавших из Каффы после ее захвата османской армией, в последующей героической обороне Мангупской крепости летом - осенью 1475 года.

Ключевые слова: Мангупское городище, Византия, княжество Феодоро, Генуэзская Газария, дворец, энколпион.

Цитирование. Науменко В. Е. «Латиняне» на Мангупе. Уникальный западноевропейский крест-энколпион из раскопок княжеского дворца Мангупского городища: проблемы атрибуции и датировки // Вестник Волгоградского государственного университета. Серия 4, История. Регионоведение. Международные отношения. - 2020. - Т. 25, № 6. - С. 100-115. - DOI: https://doi.org/10.15688/jvolsu4.2020.6.7

Введение. Начиная с 2006 г. одним из основных объектов археологических исследований Мангупского городища, крупнейшей средневековой крепости Юго-Западного Крыма, является ее княжеский дворец, расположенный в центральной части Мангупского плато (рис. 1). За эти годы на площади раскопа более 2800 кв. м изучены, вероятно, все основные архитектурно-археологические комплексы дворцового ансамбля и сформирована необходимая источниковая база для решения многих вопросов его истории (об истории изучения дворца см.: [14, c. $388-396 ; 18$, с. 139-142]).

К числу наиболее важных результатов этих исследований относятся прежде всего заключение об узкой (в пределах 14251475 гг.) хронологии собственно резиденции правителей княжества Феодоро на Мангупе $[18$, c. 144$]$ и новая концепция композиционно-планировочного решения дворца [19, c. 64-69]. Еще одним важным итогом работ является открытие на его площади нескольких ярусов застройки додворцового и постдворцового времени. Таким образом, дворец принадлежит к числу немногих археологических объектов Мангупа, в стратиграфии которых представлены материальные свидетельства всех основных периодов истории городища - от ранневизантийского до османского времени [17, с. 54-58].

На сегодняшний день, помимо завершения полевой стадии изучения Мангупского дворца, важнейшим направлением его дальнейших исследований является кропотливая работа по систематизации, атрибуции и вве- дению в научный оборот массива полученных материальных источников $[10 ; 12-14 ; 22-24$; $38]$. Именно здесь содержится основной ресурс информации для интерпретации многих процессов, происходивших на городище и в целом на территории Горного Крыма в эпоху Средневековья. При этом важно отметить, что степень информативности тех или иных категорий вещественных источников далеко не всегда напрямую связана с их массовостью, как в случае, например, с керамическими материалами. Зачастую даже отдельные находки из группы «small finds» могут стать основанием для рассмотрения новых или до сих пор слабо изученных сюжетов в истории Мангупского городища.

Примером такой находки из раскопок Мангупского дворца, несомненно, является уникальный серебряный крест-энколпион западноевропейского типа, не имеющий аналогов среди материалов многолетних раскопок городища и избранный нами в качестве предмета настоящего исследования. Как показывает его анализ, данный предмет личного благочестия, скорее всего, служит редким свидетельством присутствия в третьей четверти XV в. среди населения столицы княжества Феодоро выходцев из Северной Италии, вероятно представителей католического духовенства. Интерес к этой находке обусловлен еще и тем, что она явно диссонирует с общевизантийским характером материальной культуры городища в интересующий нас период времени, сохранявшим по-прежнему, несмотря на формирование с начала XIII в. новой политической карты полуострова, традиционные 


\section{ВИЗАНТИЙСКАЯ ТАВРИКА}

церковно-политические и торгово-экономические связи с Константинополем и другими крупными городскими центрами Византийской империи.

Методы. Проведенное исследование носит комплексный характер. При описании креста-энколпиона использованы традиционные методы искусствоведческого анализа, для определения материала изделия - данные рентгенофлюоресцентных исследований. Атрибуция находки, с учетом ее обнаружения в верхнем культурном горизонте Мангупского дворца в качестве «переотложенного» археологического материала, выполнена главным образом на основе общепринятого в археологической науке метода аналогий. Напротив, анализ исторического контекста памятника потребовал сопоставления известных данных археологических и нарративных источников по истории Мангупа XV в., в том числе имеющихся сведений о контактах политической элиты Генуэзской Газарии и княжества Феодоро.

Описание. Интересующая нас находка обнаружена в 2019 г. при выборке верхнего (дернового) слоя на западном участке исследований дворца, на площади археологического квадрата № 46 (рис. 1). Она представляет собой равноконечный литой серебряный крестэнколпион с плакировкой желтым металлом (золотом) и треугольными завершениями на концах, которые повторяют стилизованную форму цветочных бутонов (рис. 2) ${ }^{2}$. Обе створки энколпиона, очевидно, являются отливками одной литейной формы, они скреплены четырьмя цилиндрическими заклепками-гвоздиками в центре треугольных выступов на концах креста. После отливки изображения на обеих сторонах изделия подверглись незначительной гравировке контурных линий. Общие размеры креста $-4,25 \times 2,93 \mathrm{~cm}$, толщина - 1,10 см; толщина лицевой и оборотной створок $-0,40-0,67$ и 0,19-0,43 см соответственно, диаметр отверстий заклепок - 0,17 cм.

Необходимо отметить небольшое несовпадение при стыковке створок энколпиона, видимое на обороте его горизонтальной оси. Трудно сказать, является ли оно обычным дефектом процесса отливки или речь идет о позднейшей сборке нашего креста из створок различных, уже вышедших из употребления энколпионов.
Верхний конец лицевой створки креста завершается овальным плоским выступом с отверстием для кольца, округлого в сечении, для подвешивания, очевидно, нагрудной цепи. Кольцо отлито из серебра такого же элементного состава, как и энколпион; его диаметр 1,25 см, толщина - 0,18 см. В целом крест имеет хорошую сохранность, за исключением деформации его нижней части, где утрачена часть заклепки, и общей потертости рельефных деталей.

На лицевой стороне креста представлена сцена Распятия, выполненная в западнохристианской традиции: тело Иисуса Христа, несколько сползая вдоль основного ствола креста, резко повернуто влево, голова опущена ниже рук и наклонена к левому плечу. На обороте энколпиона - изображение Богоматери Одигитрии с младенцем на левой руке и склоненной к нему головой (так называемая сцена Умиления). Черты лица и детали одежды изображенных на обеих сторонах креста изза потертости практически не видны. Также слабо просматривается сюжет орнамента на плоских поверхностях энколпиона. Скорее всего, речь идет о декоре растительного характера - стилизованных изображениях цветочных бутонов на концах креста и линиях побегов растений между ними.

Анализ. Данный раздел включает наблюдения в отношении атрибуции, датировки и исторического контекста находки. С учетом широких возможностей для ее интерпретации мы склонны рассматривать выводы исследования как предварительные, требующие своего продолжения, в том числе на основе новых археологических материалов.

Несмотря на незавершенность металлографических исследований, сомневаться в принадлежности изделия к особой категории предметов личного христианского благочестия - нательным крестам-энколпионам - не приходится ${ }^{3}$. Данный разряд христианских древностей хорошо известен в литературе благодаря многочисленным публикациям таких находок из раскопок византийских памятников, а также общим сводам «византийских» (в широком смысле) энколпионов IX-XIV вв. с территории Византии, Древней Руси, Балкано-Дунайского и Карпато-Днестровского регионов, изданным Г.Ф. Корзухиной и 
А.А. Песковой [30], Б. Питаракис [47], Л. Дончевой-Петковой [21] и С. Рябцевой [48]. Не вдаваясь в детали сложившихся представлений о терминологии, центрах производства, типологии и иконографии крестов-реликвариев (см. об этом: [40]), подчеркнем важный для нашего исследования вывод об их назначении: энколпионы, несмотря на свою многочисленность и морфологически-иконографические стандарты, практически всегда являются неординарными находками для любого археологического памятника или местности и относятся к числу предметов личного благочестия действовавших здесь представителей христианского духовенства.

Кресты-энколпионы также хорошо известны на памятниках средневековой Таврики, начиная от Херсона, что неудивительно с учетом его особой роли в церковно-политической истории региона [37, с. 236-245, 518-528, № 186-202], и практически на всех крупных городских центрах полуострова, где сохранились следы жизнедеятельности местных христианских общин (наиболее полные сводки находок см.: $[15 ; 34$, с. 165-171]; неучтенные либо опубликованные позднее кресты-мощевики см.: $[4$, с. 103 , рис. $190 ; 5$, с. 9, ил. 2,3 , ил. $3 ; 43$, с. 117 , рис. $37 ; 46 ; 35$, с. $103-109$, рис. 1,2 , рис. $2,1,3-4])$. Подавляющее большинство таких крестов датируются исследователями в широких пределах - от IX-X до XIII-XIV веков. Однако эта хронология не выглядит совершенной. Энколпионы продолжали использоваться в Таврике и позднее, о чем свидетельствуют их находки в слое пожара третьей четверти XV в. при раскопках храма у подножия г. Килиса-Кая [35, с. 104, 109] и в слоях разрушения двух поздних квартальных церквей XV-XVI вв. Мангупского городища, посвященных св. Константину [15, c. $356-357$, рис. $2,1,3]$ и св. Георгию [16, c. 66 , ил. 30$]$.

Казалось бы, источниковая база исследования выглядит достаточной для точной атрибуции любых новых материалов, тем не менее при изучении энколпиона из раскопок Мангупского дворца мы столкнулись с определенной проблемой - отсутствием прямых или даже близких ему аналогий среди опубликованного массива крестов-мощевиков на памятниках средневекового Крыма и других регионов византийского православия. Ее решение выглядит несколько неожиданным. По форме, орнаментации и иконографии изображений чрезвычайно близкими нашей находке оказывается небольшая группа «латинских» литых серебряных нательных крестов конца XIV-XV вв., обнаруженных в разное время на памятниках южнобережного Крыма, которые в этот период входили в состав так называемой Генуэзской Газарии - особого политического образования, включавшего все территориальные владения Генуи в Крыму и в Северном Причерноморье (подробнее о термине см.: [8]).

Рассматриваемая группа «латинских» крестов-тельников состоит всего из четырех предметов. Первые два креста, отлитые в одной форме, с трехлопастными завершениями концов, украшенных цветочными бутонами или пальметтами, и различными комбинациями деталей сцен Распятия и Богоматери Одигитрии (с младенцем на правой руке) при монтаже, происходят из Ай-Васильского клада, обнаруженного еще в 1901 г. на территории Ялты. Клад включал также 61 серебряную монету, в том числе 43 генуэзско-татарских аспра, четыре акче крымского хана Хаджи-Гирея (1441-1466) и дирхем одного из ранних правителей Большой Орды хана Махмуда (1459-1465), серебряную чашу, медное блюдо, фрагмент серебряной цепи и три серебряных перстня, щиток одного из которых представлял собой напаянный дукат венецианского дожа Томмазо Мочениго (1413-1423) [25; 31, с. 256-259, рис. 9] (о хане Махмуде см.: [42, с. 189-190]). По замечанию М.Г. Крамаровского, наиболее поздняя монета из клада - дирхем хана Махмуда - позволяет датировать его около 1465 г. или второй третью $\mathrm{XV}$ в. [31, с. 257].

Третий «латинский» нательный крест был найден в 1995 г. в ходе раскопок христианского монастырского комплекса X-XVI вв. на юго-восточном склоне г. Аю-Даг, в бухте Панаир [1, с. 19-20, рис. 97-98; 3, с. 14-15, рис. 56]. Точный стратиграфический контекст находки в опубликованных материалах исследований отсутствует. По наблюдениям автора раскопок, крест происходит из культурного слоя на участке к северу от монастырской ограды (так называемое помещение № 7), где 


\section{ВИЗАНТИЙСКАЯ ТАВРИКА}

во второй половине XIV-XVI вв. функционировал некрополь монастыря. По аналогии с крестами из Ай-Васильского клада находка датирована концом XIV-XV вв. [1, с. 19-20]. Со своей стороны заметим, что морфология аю-дагского креста, особенно в части оформления его концов, иконография изображений, прежде всего сцены Распятия, позолоченность фигуры Богоматери являются наиболее близкими энколпиону из раскопок Мангупского дворца. Пожалуй, единственным серьезным отличием между ними выступает фоновый орнамент в виде сетчатой штриховки на обеих сторонах креста из Аю-Дага, отсутствующий на мангупской находке.

Наконец, последний литой нательный крест интересующей нас группы предметов личного благочестия с «латинскими» чертами происходит из раскопок 2005 г. генуэзской крепости Чембало. Здесь он был обнаружен в нижних слоях заполнения воротной башни № 2 (слои № 11-12), которые по сопутствующему материалу датируются, скорее всего, первой третью XV вв. [2, с. 14-16, рис. 84, 88]. На лицевой стороне креста-тельника - стилизованное изображение сцены Распятия в западнохристианской традиции; свободная поверхность покрыта сетчатой штриховкой в технике гравировки. Оборот изделия - гладкий.

Анализируя перечисленные предметы личного благочестия, нельзя не обратить внимания на их поразительное, до деталей, сходство с мангупской находкой по всем основным признакам - морфологическим (равноконечные кресты с трехлопастными или близкими к ним треугольными концами), иконографическим (западнохристианская трактовка сцен Распятия Иисуса Христа и Умиления в образе Богоматери Одигитрии), технологическим (серебряное литье с последующей гравировкой линий и изображений в высоком рельефе; использование техники плакировки золотом последних) и орнаментальным (стилизованные изображения цветочных бутонов или пальметт, побегов растений; использование фоновой сетчатой штриховки). Это, безусловно, свидетельствует об их общей («латинской») ремесленной традиции и едином центре изготовления.

М.Г. Крамаровский, рассматривая находки крестов из Ай-Василя и Аю-Дага, пришел к справедливому выводу о том, что все они являются продукцией одной мастерской Каффы, в которой работал как стипендиарий фактории выходец из Северной Италии (Лигурии?). На это, по его мнению, указывают «латинский» стиль изделий и отсутствие прямых аналогий им среди подобных предметов личного благочестия в городах Латинской Романии и в самой Италии [31, с. 257]. Еще одно важное заключение исследователя - принадлежность клада с крестами из Ай-Василя священнику находившегося там католического прихода, что свидетельствует о попытке усиления католической пропаганды среди местного, в основном православного, населения южнобережной Готии [31, с. 258-259].

С этой атрибуцией интересующей нас группы «латинских» крестов из Крыма, которая теперь расширяется за счет находок из Чембало и Мангупа, мы в целом согласны. В таком случае вряд ли можно говорить об их значительной хронологии. С учетом стипендиарного характера условий работы для приезжего мастера-ремесленника в Каффе, скорее всего, речь идет об одном или двух десятилетиях функционирования мастерской, не более. Короткий по времени накопления клад из Ай-Василя, как лучше всего датированный археологический комплекс с такими крестами, позволяет предметно говорить о периоде их выпуска - в пределах третьей четверти $\mathrm{XV}$ в., не позднее, так как завоевание Крыма Османской империей летом - осенью 1475 г. полностью разрушило систему политического управления и организации ремесла и торговли Генуэзской Газарии в регионе. Нужно также сказать, что эта датировка для «латинского» креста-энколпиона из раскопок Мангупского дворца хорошо вписывается в стратиграфию памятника, в которой археологические комплексы и культурные напластования 14501475 гг. достаточно выразительны [17, с. 57].

Несколько слов об историческом контексте находки применительно к истории Мангупского городища. Безусловно, она представляется неординарной, ввиду полного отсутствия каких-либо материальных свидетельств о католическом духовенстве на Мангупе в $\mathrm{XV}$ в. и крайней редкости таковых вообще для выходцев из Италии, и важной, в свете хорошо известных регулярных контактов админи- 
страции Генуэзской Газарии и политической верхушки княжества Феодоро в этот период. По сути, за многие годы раскопок памятника можно говорить, с разной степенью надежности, лишь о двух предметах итальянского происхождения, обнаруженных здесь. Уверенно к ним относится золотой перстень с родовым гербом генуэзской семьи Спинола, найденный в 1913 г. в одной из поздних могил на территории Большой трехнефной базилики [33, с. 298] (о перстне см.: [31, с. 245-251, рис. 1; 32]), предположительно - граффити геральдического характера на тыльной стороне надгробия с территории караимского кладбища в верховьях балки Табана-дере. Последнее состоит из двух изображений родовых гербов в виде щитов треугольной (с тремя штандартами) и подпрямоугольной (с разлинейкой вертикальными и косыми линиями) форм, между которыми помещены христограмма и схематическое изображение «вавилона» (?) с греческими буквами [29, с. 250-251, рис. 1]. Несмотря на неясный до конца стратиграфический контекст обеих находок, их соотнесение с историей Мангупа интересующего нас периода времени вполне допустимо.

Что же может означать находка «латинского» креста-энколпиона в культурном слое третьей четверти XV в. одного из центральных объектов городища, накануне османского вторжения в пределы княжества Феодоро?

В свое время М.Г. Крамаровский, пытаясь объяснить находку личного перстня одного из представителей генуэзской аристократической фамилии Спинола на Мангупе, погребенного на территории кафедрального собора Готской митрополии Константинопольского патриархата, пришел к выводу о возможности такого захоронения лишь в условиях экстремальной ситуации на городище, которая могла сложиться во время турецкой осады крепости летом - осенью 1475 года. Другой вариант его интерпретации - военный трофей [32, с. 386]. С учетом наших знаний об истории генуэзско-феодоритских отношений в XV в., по-прежнему во многом основанных на их интерпретации А.А. Васильевым $[49$, p. 201-264] (из более поздних исследований, расширяющих проблематику и круг источников, см.: [36; 26 , с. $39-40,51-52 ; 6$, с. $417-$ $418 ; 20])$ и явно уступающих, по проработке деталей, степени изученности контактов Феодоро с Трапезундской империей $[41 ; 27$, с. 416-417] или Молдавским княжеством [11], обе эти версии применительно в нашему энколпиону кажутся вполне обоснованными. Хотя случай с его трофейным происхождением, в первую очередь из-за простоты решения проблемы, представляется все-таки маловероятным. Тем не менее позволим себе назвать еще две возможные причины, объясняющие присутствие креста на памятнике для периода 1450-1475 годов.

Прежде всего, крест с вложениями, безусловно являвшийся личным атрибутом одежды католического священнослужителя, мог оказаться на Мангупе в результате прибытия в столицу княжества Феодоро неизвестного в источниках генуэзского посольства с целью учреждения здесь постоянной католической миссии (монастыря, прихода). Несмотря на отсутствие в настоящий момент каких-либо указаний на это в источниках, данная гипотеза нам не кажется невозможной с учетом активизации и разнообразия генуэзско-феодоритских контактов после гибели Византии в 1453 г. в условиях реального роста османской угрозы для Крыма с этого времени и общей слабой изученности истории католической церкви на полуострове в поздневизантийский период (некоторые общие сведения см.: [7, с. 32-34; 28]). Сложившиеся в историографии представления о том, что организационная деятельность католического духовенства по обустройству собственных епархий или приходов, как и миссионерство западнохристианских монашеских орденов (прежде всего францисканцев и доминиканцев), была ограничена политико-административными пределами Генуэзской Газарии и не затронула области Горного Крыма, могут быть серьезно скорректированы при появлении любого нового документа, как в случае с недавней публикацией Р. Хауталой письма Ладислава, главы францисканских миссий в Северном Причерноморье, свидетельствующего об основании им около 1287 г. церкви Св. Девы и соответствующей католической миссии в Кырк-Оре (Чуфут-Кале; в тексте - Керквети) [44; 45, с. 7273] (об исторической географии Генуэзской Газарии см.: [9]). 


\section{ВИЗАНТИЙСКАЯ ТАВРИКА}

Другой возможной причиной, по которой «латинский» крест-энколпион мог оказаться в культурном слое Мангупского княжеского дворца, является включение в состав генуэзского посольства в Феодоро католического священника. Для периода 1450-1475 гг. нам известно о множестве дипломатических контактов между Мангупом и Каффой, сведения о которых сохранили массарии - бухгалтерские книги казначейства последней. Наиболее интересны в связи с темой исследований упоминания о двух посольствах генуэзцев в столицу княжества Феодоро в 1455 и 1465 гг., а также о пребывании мангупского князя Исаака около 1471 г. в самой Каффе, завершившемся заключением мирного договора между государствами, которому, безусловно, предшествовало прибытие генуэзской дипломатической миссии на Мангуп (подробнее о них см.: [49, p. 231-233, 236-237; 36, с. 354 358,$402 ; 20$, с. 137-139]). Нам неизвестен полный состав этих итальянских посольств в Феодоро, однако присутствие в них представителей католического духовенства кажется вполне логичным.

Результаты. Обнаруженный в культурном слое Мангупского княжеского дворца крест-энколпион западноевропейского типа является важным историческим источником, позволяющим с учетом имеющихся письменных и археологических свидетельств вновь обратиться к изучению политических контактов Генуэзской Газарии и княжества Феодоро в XV в., а также характеру и направлениям католической экспансии на Крымском полуострове в это время.

Проведенный всесторонний анализ находки делает возможным соотнести ее с небольшой группой нательных литых серебряных крестов с «латинскими» чертами, которые, очевидно, выпускались в течение третьей четверти XV в. в одной из ремесленных мастерских Каффы. Их автором являлся мастер-стипендиарий, скорее всего переселившийся в столицу Генуэзской Газарии из Северной Италии.

Среди множества причин, по которым данный энколпион как обязательный атрибут одежды католического священнослужителя мог оказаться на Мангупе, наиболее веро- ятными представляются следующие: неизвестное в источниках генуэзское посольство в столицу православного княжества Феодоро в период 1450-1475 гг. с целью учреждения здесь постоянной католической миссии (прихода, монастыря); присутствие католического священника в составе крупных посольств Каффы ко двору правителей Феодоро в 1455, 1465 или около 1471 гг; участие генуэзцев, бежавших из Каффы после ее захвата османской армией, в последующей героической обороне Мангупской крепости летом - осенью 1475 года.

Благодарности. Выражаем признательность А.Г. Герцену, руководителю Мангупской археологической экспедиции ФГАОУ ВО «Крымский федеральный университете им. В.И. Вернадского», за возможность самостоятельной публикации находки, а также В.В. Майко и Э.А. Хайрединовой за помощь в ее атрибуции. Графическая фиксация креста-энколпиона выполнена В.К. Ганцевым.

\section{ПРИМЕЧАНИЯ}

\begin{abstract}
${ }^{1}$ Исследование выполнено в рамках проекта РФФИ №19-09-00124 «Дворцовый комплекс Мангупского городища - резиденция правителей княжества Феодоро в Юго-Западном Крыму. Проблемы хронологии, планировки и архитектурной реконструкции памятника».

The study was carried out within the framework of the project of Russian Foundation for Basic Research №19-09-00124 “The palace complex of the Mangup fortress - the residence of the rulers of the principality of Theodoro in the South-Western Crimea. Problems of chronology, planning and architectural reconstruction of the monument".

${ }^{2}$ Определение материала изделия выполнено с помощью рентгенофлюоресцентного метода в лаборатории Физико-технического института ФГАОУ ВО «Крымский федеральный университет им. В.И. Вернадского». Авторы исследования Е.М. Максимова и И.А. Наухацкий.

${ }^{3}$ В ходе металлографического анализа находки осталась неизученной ее внутренняя полость, где должны сохраняться остатки вложений (чудотворных мощей). Примеры подобных исследований см.: [39].
\end{abstract}


B.E. Науменко. «Латиняне» на Мангупе. Уникальный западноевропейский крест-энколпион

\section{ПРИЛОЖЕНИЕ}

R3 (545,93 M)

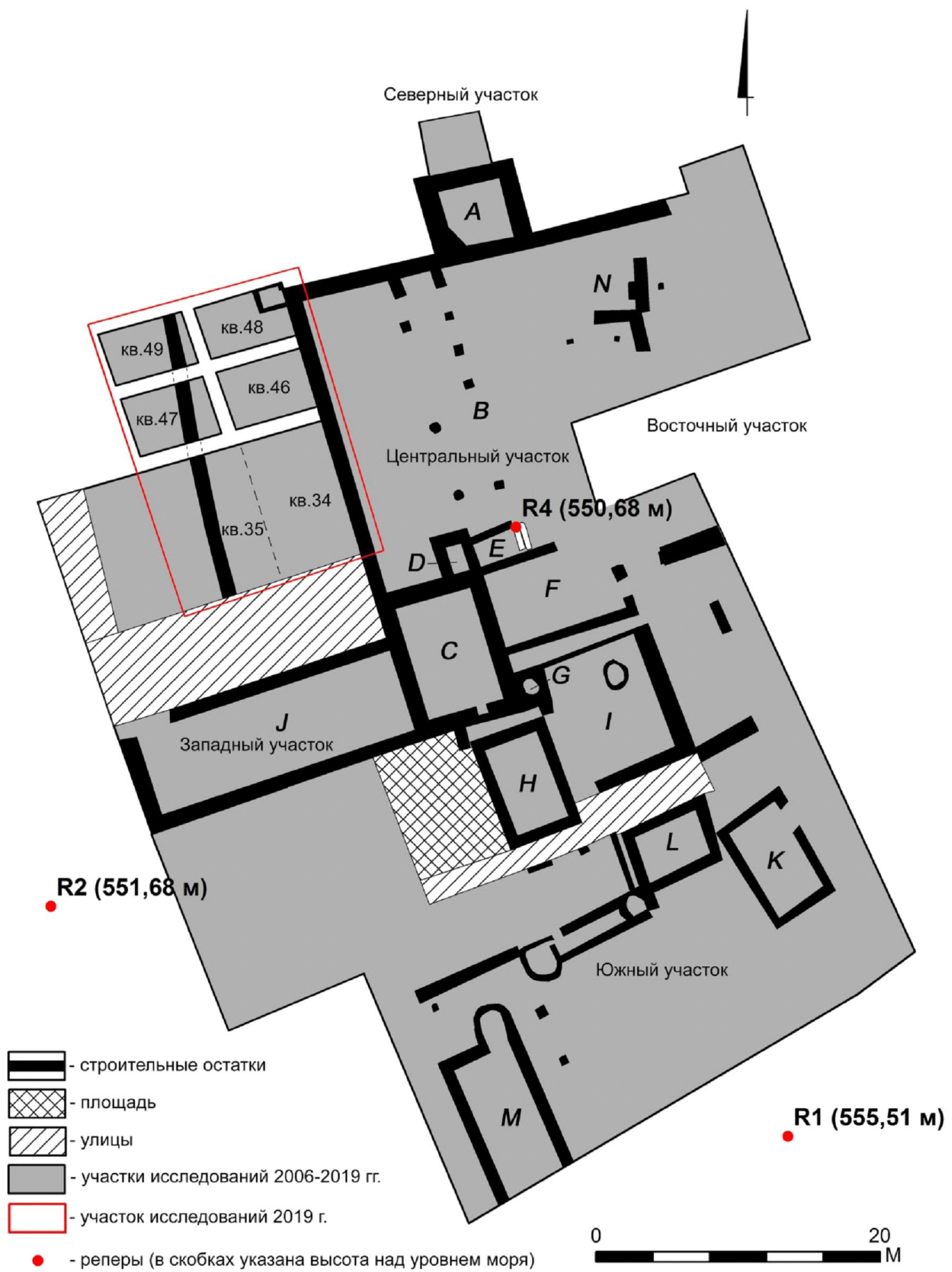

Рис. 1. Княжеский дворец Мангупского городища. Общий план участка исследований 2006-2019 гг.

Fig. 1. Prince's Palace of Mangup. General Plan of the Research Area 2006-2019 


\section{ВИЗАНТИЙСКАЯ ТАВРИКА}

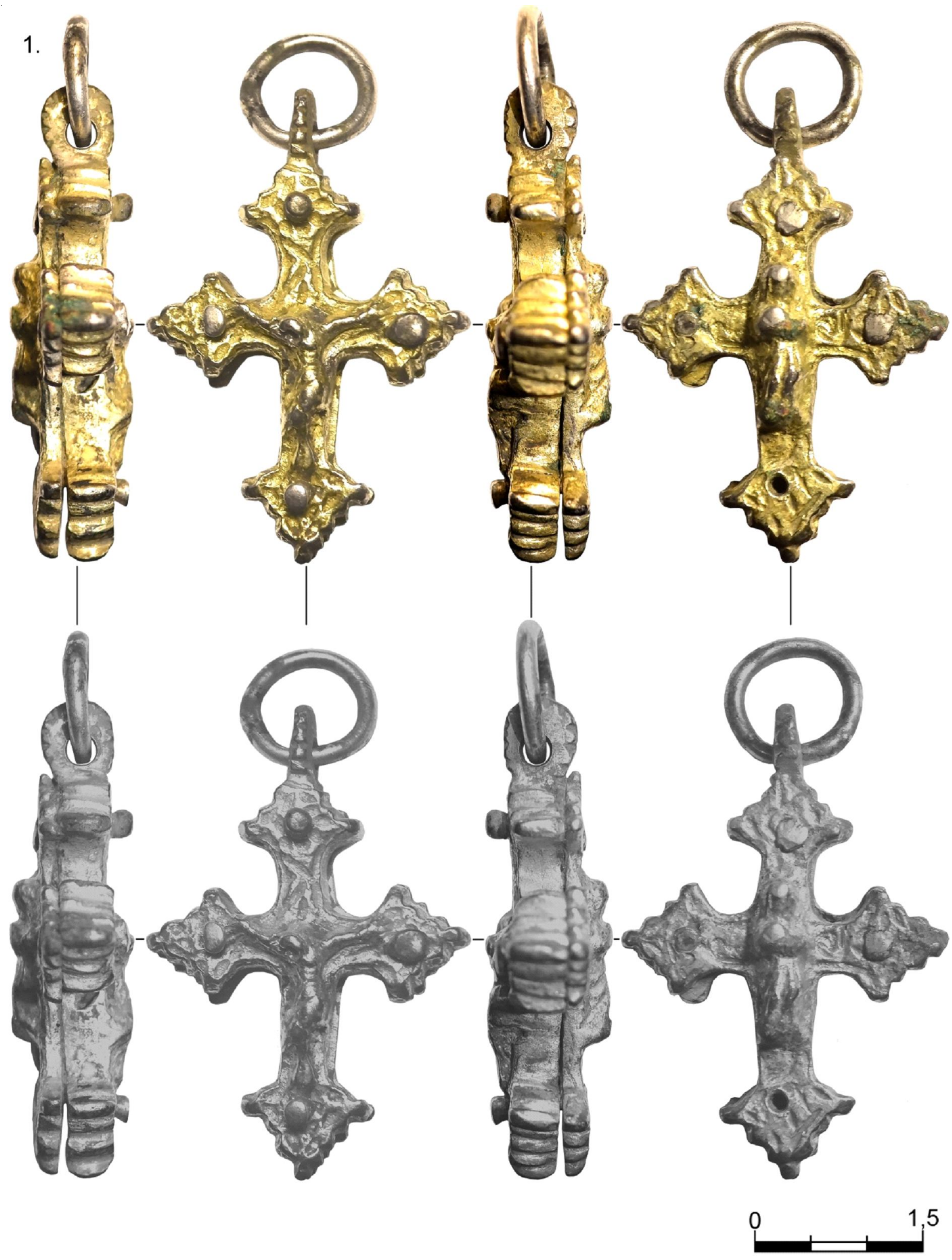

Рис. 2. «Латинский» крест-энколпион третьей четверти XV в. из раскопок Мангупского княжеского дворца (2019 г., квадрат № 46, дерновый слой)

Fig. 2. "Latin" Cross-Encolpion of the third quarter of the $15^{\text {th }}$ Century from the excavations of the Prince's Palace of Mangup (2019, quadrant no. 46, top layer) 


\section{СПИСОК ЛИТЕРАТУРЫ}

1. Адаксина, С. Б. Монастырский комплекс XXVI вв. на г. Аю-Даг / С. Б. Адаксина. - СПб. : Изд-во Гос. Эрмитажа, 2002. - $116 \mathrm{c}$.

2. Адаксина, С. Б. Отчет об археологических исследованиях средневековой крепости Чембало (г. Балаклава) в 2005 г. / С. Б. Адаксина, В. П. Кирилко, В. Л. Мыц. - СПб. ; Симферополь : Изд-во Гос. Эрмитажа, 2006. - 223 с.

3. Адаксина, С. Б. Работы Южно-Крымской археологической экспедиции / С. Б. Адаксина // Археологические исследования в Крыму. 1995 год / отв. ред. В. Л. Мыц. - Симферополь : Сонат, 2007. C. 11-15.

4. Адаксина, С. Б. Отчет об археологических исследованиях средневековой крепости Чембало (г. Балаклава) в 2008-2009 гг. / С. Б. Адаксина, В. Л. Мыц, С. В. Ушаков. - СПб. ; Симферополь : Изд-во Гос. Эрмитажа, 2010. - 303 с.

5. Айбабин, А. И. Предметы христианского культа из раскопок 2003-2008 гг. на городище ЭскиКермен / А. И. Айбабин, Э. А. Хайрединова // Труды Государственного Эрмитажа. - 2013. - [Т.] 69 : Византия в контексте мировой культуры : сб. науч. тр., посвящ. памяти А.В. Банк (1906-1984). - С. 7-21.

6. Акты генуэзских нотариев, составленные в Каффе и в других городах Причерноморья в XIVXV вв. / под ред. С. П. Карпова; сост. М. Г. Альваро [и др.]. - М. ; СПб. : Алетейя, 2018. - 760 с. - (Причерноморье в Средние века ; вып. Х).

7. Богданова, Н. М. Церковь в Херсоне в XXV вв. / Н.М. Богданова // Византия. Средиземноморье. Славянский мир : сборник. - М. : Изд-во МГУ, 1991.- С. 19-49.

8. Бочаров, С. Г. Археология Генуэзской Газарии. Введение в научную проблему / С. Г. Бочаров // Византийское содружество: традиции и смена парадигм : тез. докл. XXII Всерос. науч. сес. византинистов / под ред. М. В. Графианского, Т. В. Кущ. - Екатеринбург : Изд-во УрФУ, 2019. - С. 24-27.

9. Бочаров, С. Г. Историческая география крымских владений Генуэзской Газарии (1275-1475) / С. Г. Бочаров // Генуэзская Газария и Золотая Орда. Т. 2 / под ред. С. Г. Бочарова, А. Г. Ситдикова. Казань ; Кишинев : Ин-т археологии им. А.Х. Халикова АН РТ, 2019. - С. 741-770.

10. Ганцев, В. К. Трехручная стеклянная лампада XV в. из раскопок княжеского дворца Мангупского городища / В. К. Ганцев // XXI Боспорские чтения «Боспор Киммерийский и варварский мир в период античности и средневековья. Объекты искусства в археологическом контексте» : материалы Междунар. науч. конф. / ред.-сост. В. Н. Зинько, Е. А. Зинько.-Симферополь ; Керчь : НИЦ ИАК КФУ ; ИАК РАН; ЦАИБФ «Деметра», 2020. - С. 84-89.
11. Герцен, А. Г. Молдавия и княжество Феодоро в 1475 г. / А. Г. Герцен // Античная древность и средние века. - 2004. - Вып. 35. - С. 226-240.

12. Герцен, А. Г. Сасанидский перстень из раскопок Мангупа / А. Г. Герцен // IX Международная Крымская конференция по религиоведению «Небесные патроны и земные служители культа» : тез. докл. и сообщ. - Севастополь : Херсонес Таврический, 2007. - С. 18-19.

13. Герцен, А. Г. Золотоордынское зеркало из раскопок княжеского дворца Мангупа / А. Г. Герцен // Откровения древнего Солхата. - Керчь : Боспор, 2010.- С. 96-105.

14. Герцен, А. Г. Археологический комплекс третьей четверти XV в. из раскопок княжеского дворца Мангупского городища / А. Г. Герцен, В. Е. Науменко // Труды Государственного Эрмитажа. 2010. - [Т.] 51 : Византия в контексте мировой культуры : материалы конф., посвящ. памяти А.В. Банк (1906-1984). - С. 387-419.

15. Герцен, А. Г. Древнерусские энколпионы из Юго-Западного Крыма / А. Г. Герцен, Т. Ю. Яшаева // Славяно-русское ювелирное дело и его истоки : материалы Междунар. науч. конф., посвящ. 100 -летию со дня рождения Г.Ф. Корзухиной. СПб. : Нестор-История, 2010. - С. 355-362.

16. Герцен, А. Г. Население Дороса-Феодоро по результатам комплексного археолого-антропологического анализа некрополей Мангупского городища (IV-XVII вв.) / А. Г. Герцен, В. Е. Науменко, Т. Ю. Шведчикова ; отв. ред. А. И. Айбабин. - М. ; СПб. : Нестор-История, 2017. - 272 с.

17. Герцен, А. Г. Княжеский дворец Мангупского городища. Стратиграфия участка исследований 2006-2017 гг. (предварительное сообщение) / А. Г. Герцен, В. Е. Науменко, А. А. Душенко // X Международный Византийский семинар «Хع науч. конф. / отв. ред. Н. А. Алексеенко. - Севастополь : ИАК РАН, 2018. - С. 53-58.

18. Герцен, А. Г. Основные итоги и перспективы исследований княжеского дворца Мангупского городища / А. Г. Герцен, В. Е. Науменко, А. А. Душенко // XX Боспорские чтения «Боспор Киммерийский и варварский мир в период античности и средневековья. Основные итоги и перспективы исследований» : материалы Междунар. науч. конф. / ред.-сост. В. Н. Зинько, Е. А. Зинько. Симферополь ; Керчь : НИЦ ИАК КФУ; ЦАИ БФ «Деметра», 2019. - С. 139-148.

19. Герцен, А. Г. Княжеский дворец Мангупского городища. Проблемы архитектурно-археологической реконструкции памятника / А. Г. Герцен, В. Е. Науменко, А. А. Душенко, Д. В. Иожица // Актуальные вопросы охраны и использования культурного наследия Крыма : сб. материалов VI Науч.- 
практ. конф. / гл. ред. В. Е. Науменко. - Симферополь : Ариал, 2019. - С. 60-70.

20. Джанов, А. В. Каффа, Крымское ханство и османы в 1454-1456 гг. По данным книг массарии Каффы / А. В. Джанов // Сугдейський збірник. 2019. - Вип. 2(VIII). - C. 79-373.

21. Дончева-Петкова, Л. Средновековни кръстове-енколпиони от България (IX-XIV вв.) / Л. Дончева-Петкова. - София : Проф. Марин Дринов, 2011. $735 \mathrm{c}$.

22. Душенко, А. А. Предметы из кости и рога из раскопок дворца правителей Феодоро (Мангуп) / А. А. Душенко // Материалы по археологии, истории и этнографии Таврии. - 2015. - Вып. ХХ. C. $233-262$.

23. Душенко, А. А. Нумизматический комплекс Мангупского княжеского дворца: статистический обзор (раскопки 2006-2018 гг.) / А. А. Душенко // XII Международный Византийский семинар

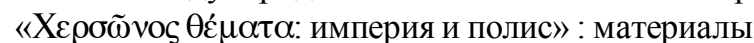
науч. конф. / отв. ред. Н. А. Алексеенко. - Симферополь : Колорит, 2020. - С. 91-98.

24. Душенко, А. А. Металлические зеркала из раскопок Мангупского княжеского дворца / А. А. Душенко // XXI Боспорские чтения «Боспор Киммерийский и варварский мир в период античности и средневековья. Объекты искусства в археологическом контексте» : материалы Междунар. науч. конф. / ред.-сост. В. Н. Зинько, Е. А. Зинько. - Симферополь ; Керчь : НИЦ ИАК КФУ; ИАК РАН; ЦАИ БФ «Деметра», 2020. - С. 101-109.

25. Залесская, В. Н. Клад из Ай-Василя: об историко-культурных связях средневековой Ялиты / В. Н. Залесская // Античная древность и средние века. - 1995. - Вып. 27 : Византия и средневековый Крым. - С. 98-101.

26. Карпов, С. П. Регесты документов Фонда Diversorum Filze Секретного Архива Генуи, относящиеся к истории Причерноморья / С. П. Карпов // Причерноморье в средние века. - СПб. : Алетейя, 1998. - Вып. III. - С. 9-81.

27. Карпов, С. П. История Трапезундской империи / С. П. Карпов. - СПб. : Алетейя, 2007. - 624 с.

28. Карпов, С. П. Вера и церковь в Генуэзской Газарии / С. П. Карпов // История Крыма. В 2 т. Т. 1 / отв. ред. А. В. Юрасов. - М. : Кучково поле, 2019. C. 353-355.

29. Кашовская, Н. В. К итогам изучения караимского некрополя в ущелье Табана-дере (Мангуп): проблемы хронологии и периодизации / Н. В. Кашовская // Материалы по археологии, истории и этнографии Таврии. -2017. - Вып. XXII. -C. 239-277.

30. Корзухина, Г. Ф. Древнерусские энколпионы. Кресты-реликварии ХІ-ХІІІ вв. / Г. Ф. Корзухина, А. А. Пескова. - СПб. : Петерб. востоковедение, 2003. $-432 \mathrm{c}$.
31. Крамаровский, М. Г. Латинская Романия и золотоордынский Крым. Латинские перстневые находки и печати в Северном Причерноморье. Клад из Ай-Василь / М. Г. Крамаровский // Степи Европы в эпоху средневековья. Т. 1 / гл. ред. А. В. Евглевский. - Донецк : ДонГУ, 2000. - С. 245-263.

32. Крамаровский, М. Г. Перстень с родовым гербом семьи Спинола, найденный на Мангупе / М. Г. Крамаровский // Античная древность и средние века. - 2001. - Вып. 32. - С. 376-386.

33. Лепер, Р. Х. Сообщение о раскопках на Мангупе в 1913 г. / Р. Х. Лепер // Известия Таврической Ученой Архивной комиссии. - 1914. № 51. - С. 297-300.

34. Майко, В. В. Восточный Крым во второй половине X-XII вв. / В. В. Майко. - К. : Вид. Олег Филюк, 2014. - 467 с.

35. Майко, В. В. Комплекс христианских раритетов из раскопок храма у подножия горы Килиса-Кая близ Судака / В. В. Майко // Хербテ̃vо

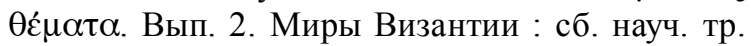
/ отв. ред. Н. А. Алексеенко. - Симферополь : ИАК PAH, 2019. - C. 103-114.

36. Мыц, В. Л. Каффа и Феодоро в XV в. Контакты и конфликты / В. Л. Мыц. - Симферополь : Универсум, 2009. - 528 с.

37. Наследие византийского Херсона / Т. Яшаева [и др.]. - Севастополь : Телескоп ; Остин : Ин-т классической археологии, 2011. - 708 с.

38. Науменко, В. Е. Княжеский дворец Мангупского городища: помещение Н южного участка комплекса (по материалам коллекции Р.Х. Лепера Государственного Эрмитажа и современных археологических исследований) / В. Е. Науменко, А. А. Душенко // Материалы по археологии, истории и этнографии Таврии. - 2017. - Вып. ХХІІ. -С. 187-238.

39. Невидимые святыни. Вложения в средневековых крестах-энколпионах по данным комплексных аналитических исследований / Н. А. Макаров [и др.] // Краткие сообщения Института археологии. -2020. - Вып. 258. - С. 25-45.

40. Пескова, А. А. Традиция изображения святых на византийских крестах-реликвариях / А. А. Пескова // Archeologia Abrahamica : Исследования в области археологии и художественной традиции иудаизма, христианства и ислама / ред.-сост. Л. А. Беляев. - М. : Индрик, 2009. - С. 285-312.

41. Степаненко, В. П. Владетели Феодоро и византийская аристократия XV в. / В. П. Степаненко // Античная древность и средние века. 2001. - Вып. 32. - С. 335-353.

42. Трепавлов, В. В. Большая Орда // История татар с древнейших времен. В 7 т. Т. 4. Татарские государства XV-XVIII вв. / науч. ред. тома И. Миргалеев. - Казань : Ин-т истории им. Ш. Марджани, 2014. - C. 180-196. 
43. Турова, Н. П. Средневековый пещерный комплекс хребта Иограф над г. Ялта / Н. П. Турова // Материалы по археологии и истории античного и средневекового Крыма. - 2014. - Вып. 6. C. 93-173.

44. Хаутала, Р. Письмо Ладислава, францисканского кустодия Газарии (Каффа, 10 апреля 1287 г.) / Р. Хаутала // Золотоордынское обозрение. - 2017. T. 5, № 1. - C. 193-199.

45. Хаутала, Р. Францисканцы и доминиканцы в Золотой Орде. Развитие миссионерской деятельности до середины XIV в. / Р. Хаутала // Золотоордынское наследие. Вып. 3 : материалы VI Междунар. Золотоордынского форума «Рах Tatarica : Генезис и наследие Золотой Орды». - Казань : Ин-т истории им. Ш. Марджани АН РТ, 2019. - С. 69-86.

46. Яшаева, Т. Ю. Крест-энколпион с вложением из Херсонесской базилики 1935 г. / Т. Ю. Яшаева // Труды Государственного Эрмитажа. - 2017. [T.] 89 : Византия в контексте мировой культуры : материалы конф., посвящ. памяти А.В. Банк (19061984). - C. 81-89.

47. Pitarakis, B. Les croix-reliquaires pectorales Byzantines en bronze / B. Pitarakis. - P. : Picard, 2006. $427 \mathrm{p}$.

48. Ryabtseva, S. Pectoral Reliquary-Crosses from the Carpathian-Dniester Region, $11^{\text {th }}-16^{\text {th }}$ Centuries / S. Ryabtseva // Rome, Constantinople and NewlyConverted Europe. Vol. II / ed. by M. Salamon [et al.]. Kraków ; Leipzig : Geisteswissenschaftliches Zentrum Geschichte und Kultur Ostmitteleuropas ; Warszawa : Instytut Archeologii i Etnologii Polskiej Akademii Nauk ; Rzeszów : Instytut Archeologii Uniwersytetu Rzeszowskiego, 2012. - P. 527-543.

49. Vasiliev, A. A. The Goths in the Crimea / A. A. Vasiliev. - Cambridge ; Massachusetts : Mediaeval Academy of America, 1936. - 292 p.

\section{REFERENCES}

1. Adaksina S.B. Monastyrskiy kompleks $X_{-}$ XVI vv. na g. Ayu-Dag [Monastery complex of the $10^{\text {th }}$ $16^{\text {th }}$ centuries in Ayu-Dag]. St. Petersburg, Izdatelstvo Gosudarstvennogo Ermitazha Publ., 2002. 116 p.

2. Adaksina S.B., Kirilko V.P., Myts V.L. Otchet ob arkheologicheskikh issledovaniyakh srednevekovoy kreposti Chembalo (g. Balaklava) v $2005 \mathrm{~g}$. [Report on archaeological research of the medieval fortress of Cembalo (Balaklava) in 2005]. St. Petersburg, Simferopol, Izdatelstvo Gosudarstvennogo Ermitazha Publ., 2006.223 p.

3. Myts V.L., ed. Adaksina S.B. Raboty YuzhnoKrymskoy arheologicheskoj ekspedicii [Proceedings of the South Crimean archaeological expedition]. Arheologicheskie issledovaniya v Krymu. 1995 god
[Archaeological Researches in Crimea in 1995]. Simferopol, Sonat Publ., 2007, pp. 11-15.

4. Adaksina S.B., Myts V.L., Ushakov S.V. Otchet ob arkheologicheskikh issledovaniyakh srednevekovoy kreposti Chembalo (g. Balaklava) v 2008-2009 gg. [Report on archaeological research of the medieval fortress of Cembalo (Balaklava) in 20082009]. St. Petersburg, Simferopol, Izdatelstvo Gosudarstvennogo Ermitazha Publ., 2010. 303 p.

5. Aibabin A.I., Khairedinova E.A. Predmety khristianskogo kulta iz raskopok 2003-2008 gg. na gorodishche Eski-Kermen [Christian Religious Items from Excavations at the Eski-Kermen Settlement in 2003-2008]. Trudy Gosudarstvennogo Ermitazha [Proceedings of the State Hermitage], 2013, vol. 69: Vizantiya v kontekste mirovoy kultury: sbornik nauchnykh trudov, posvyashchennyy pamyati A.V. Bank (1906-1984) [Byzantium within the Context of the World Culture: collection of scientific papers dedicated to the memory of A.V. Bank (1906-1984)], pp. 7-21.

6. Karpov S.P., ed. Akty genuezskikh notariev, sostavlennye v Kaffe i v drugikh gorodakh Prichernomorya v XIV-XV vv. [Acts of Genoese Notaries drawn up in Kaffa and other cities of the Black Sea region in the XIV-XV centuries]. Moscow, St. Petersburg, Aletheia Publ., 2018. 760 p. (Prichernomore v Srednie veka [Black Sea Region in the Middle Ages]; vol. 10).

7. Bogdanova N.M. Tserkov v Khersone v X$\mathrm{XV}$ vv. [Church in Kherson in the X-XV centuries]. Vizantiya. Sredizemnomore. Slavyanskiy mir [Byzantium. Mediterranean. Slavic World]. Moscow, Izdatelstvo MGU Publ., 1991, pp. 19-49.

8. Bocharov S.G. Arkheologiya Genuezskoy Gazarii. Vvedenie v nauchnuyu problemu [Archaeology of Genoese Gazaria. Introduction to the scientific problem]. Gratsiansky M.V., Kushch T.V., eds. Vizantiyskoe sodruzhestvo: traditsii $i$ smena paradigm: tezisy dokladov XXII Vserossiyskoy nauchnoy sessii vizantinistov [The Byzantine Commonwealth: traditions and paradigm shift: abstracts of the $22^{\text {nd }}$ Russian scientific session of the byzantinists]. Ekaterinburg, Izdatelstvo UrFU Publ., 2019, pp. 24-27.

9. Bocharov S.G. Istoricheskaya geografiya krymskikh vladeniy Genuezskoy Gazarii (1275-1475) [Historical Geography of the Crimean Territories of the Genoese Gazaria (1275-1475)]. Bocharov S.G., Sitdikov A.G., eds. Genuezskaya Gazariya i Zolotaya Orda [The Genoese Gazaria and the Golden Horde]. Vol. 2. Kazan, Kishinev, Institut arkheologii im. A.H. Khalikova AN RT Publ., 2019, pp. 741-770.

10. Gantsev V.K. Trekhruchnaya steklyannaya lampada XV v. iz raskopok knyazheskogo dvortsa Mangupskogo gorodishcha [Three-handle glass lamp 
of the $15^{\text {th }}$ century from the excavations of the Prince's Palace of Mangup]. Zinko V.N., Zinko E.A., eds. XXI Bosporskie chteniya "Bospor Kimmeriyskiy $i$ varvarskiy mir v period antichnosti $i$ srednevekovya. Obekty iskusstva v arkheologicheskom kontekste”. Materialy mezhdunarodnoy nauchnoy konferentsii [The $21^{\text {st }}$ Bosporan Readings. Cimmerian Bosporus and the World of Barbarians in Antiquity and the Middle Ages. Objects of Art in an Archaeological Context: materials of International Scholarly Conference]. Simferopol, Kerch, NIC IAK KFU, IAK RAN, CAI BF "Demetra" Publ., 2020, pp. 84-89.

11. Gertsen A.G. Moldaviya i knyazhestvo Feodoro v $1475 \mathrm{~g}$. [Moldavia and the Principality of Feodoro in 1475]. Antichnaya drevnost i srednie veka [Antiquities and the Middle Ages], 2004, vol. 35, pp. 226-240.

12. Gertsen A.G. Sasanidskiy persten iz raskopok Mangupa [A Sasanidian Ring from the Mangup excavations]. IX Mezhdunarodnaya Krymskaya konferentsiya po religiovedeniyu "Nebesnye patrony $i$ zemnye sluzhiteli kulta”. Tezisy dokladov $i$ soobshcheniy [The $9^{\text {th }}$ International Crimean conference on Religious studies "Heavenly Patrons and Earthly Ministers of worship": abstracts]. Sevastopol, NZ “Khersones Tavricheskiy” Publ., 2007, pp. 18-19.

13. Gertsen A.G. Zolotoordynskoe zerkalo iz raskopok knyazheskogo dvortsa Mangupa [Golden Horde Mirror from the excavations of the Prince's Palace of Mangup]. Otkroveniya drevnego Solkhata [Revelations of ancient Solhat]. Kerch ; Bospor, 2010, pp. 96-105.

14. Gertsen A.G., Naumenko V.E. Arkheologicheskiy kompleks tretey chetverti XV v. iz raskopok knyazheskogo dvortsa Mangupskogo gorodishcha [An Archaeological Complex of the third quarter of the $15^{\text {th }}$ century from the Prince's Palace of the Mangup Site]. Trudy Gosudarstvennogo Ermitazha [Proceedings of the State Hermitage], 2010, vol. 51: Vizantiya v kontekste mirovoy kultury: materialy konferentsii, posvyashchennoy pamyati A.V. Bank (1906-1984) [Byzantium within the Context of the World Culture: materials of conference dedicated to the memory of A.V. Bank (1906-1984)], pp. 387-419.

15. Gertsen A.G., Yashaeva T.Yu. Drevnerusskie enkolpiony iz Yugo-Zapadnogo Kryma [Ancient Rus Reliquary Crosses from South-West Crimea]. Slavyano-russkoe yuvelirnoe delo i ego istoki. Materialy Mezhdunarodnoy nauchnoy konferentsii, posvyashchennoy 100-letiyu so dnya rozhdeniya G.F. Korzukhinoy [Slavic and Old Russian Art of Jewelry and Its Roots. Materials of International Scientific Conference dedicated to the $100^{\text {th }}$ anniversary of Gali Korzukhina's birth]. St. Petersburg, NestorIstoriya Publ., 2010, pp. 355-362.
16. Aibabin A.I., ed. Gertsen A.G., Naumenko V.E., Shvedchikova T.Yu. Naselenie Dorosa-Feodoro po rezultatam kompleksnogo arkheologoantropologicheskogo analiza nekropoley Mangupskogo gorodishcha (IV-XVII vv.) [The population of Doros-Feodoro based on the results of a comprehensive archaeological and anthropological analysis of the necropolises of the Mangup settlement (IV-XVII centuries)]. Moscow; St. Petersburg, NestorIstoriya Publ., 2017.272 p.

17. Gertsen A.G., Naumenko V.E., Dushenko A.A. Knyazheskiy dvorets Mangupskogo gorodishcha. Stratigrafiya uchastka issledovaniy 2006-2017 gg. (predvaritelnoe soobshchenie) [Prince's Palace at the Ancient City of Mangup. Stratigraphy of the 20062017 Research Area (A Preliminary Communication)]. Alekseenko N.A., ed. XMezhdunarodnyy Vizantiyskiy seminar "Chersōnos themata: 'imperiya' $i$ 'polis'”. Materialy nauchnoy konferentsii [The $10^{\text {th }}$ International Byzantine Seminar «Chersōnos themata: 'empire' and 'polis"'. Materials of scientifical conference]. Sevastopol, IAK RAN Publ., 2018, pp. 53-58.

18. Gertsen A.G., Naumenko V.E., Dushenko A.A. Osnovnye itogi i perspektivy issledovaniy knyazheskogo dvortsa Mangupskogo gorodishcha [The main Results and prospects of research of the princely palace of the Mangup settlement]. Zinko V.N., Zinko E.A., eds. XX Bosporskie chteniya "Bospor Kimmeriyskiy $i$ varvarskiy mir v period antichnosti $i$ srednevekovya. Osnovnye itogi i perspektivy issledovaniy". Materialy mezhdunarodnoy nauchnoy konferentsii [The $20^{\text {th }}$ Bosporan Readings. Cimmerian Bosporus and the World of Barbarians in Antiquity and the Middle Ages. Main Results and prospects of research: materials of International Scholarly Conference]. Simferopol; Kerch, NIC IAK KFU, CAI BF “Demetra" Publ., 2019, pp. 139-148.

19. Gertsen A.G., Naumenko V.E., DushenkoA.A., Iozhitsa D.V. Knyazheskiy dvorets Mangupskogo gorodishcha. Problemy arhitekturno-arheologicheskoy rekonstruktsii pamyatnika [Prince's Palace of Mangup settlement. Problems of architectural and archaeological reconstruction of the monument]. Naumenko V.E., ed. Aktualnye voprosy okhrany $i$ ispolzovaniya kulturnogo naslediya Kryma. Sbornik materialov VI nauchno-prakticheskoy konferentsii [Current issues of protection and use of the cultural heritage of the Crimea. Collection of materials of the $6^{\text {th }}$ Scientific and Practical conference]. Simferopol, IT “Arial” Publ., 2019, pp. 60-70.

20. Dzhanov A.V. Kaffa, Krymskoe khanstvo i osmany v 1454-1456 gg. po dannym knig massarii Kaffy [Caffa, the Crimean Khanat and the Ottomans in 1454-1456 (accoding to data from the books of Caffa Massaria]. Sugdeyskiy zbornik [Sugdeian Collection], 2019, vol. 2 (VIII), pp. 79-373. 
21. Doncheva-Petkova L. Srednovekovni krastove-enkolpioni ot Balgaria (IX-XIV vv.) [Medieval Crosses-Encolpia from Bulgaria $\left(9^{\text {th }}-14^{\text {th }}\right.$ centuries $]$. Sofiya, Akademichno izdatelstvo «Prof. Marin Drinov» Publ., 2011. 735 p.

22. Dushenko A.A. Predmety iz kosti i roga iz raskopok dvortsa praviteley Feodoro (Mangup) [Bone and Antler Artefacts Excavated in the Palace of the Princes of Theodoro (Mangup)]. Materialy po arkheologii, istorii $i$ etnografii Tavrii [Materials in Archaeology, History and Ethnography of Tauria], 2015, vol. XX, pp. 233-262.

23. Dushenko A.A. Numizmaticheskiy kompleks Mangupskogo knyazheskogo dvortsa: statisticheskiy obzor (raskopki 2006-2018 gg.) [Numismatic complex of the Prince's Palace of Mangup: statistical review (excavations 2006-2018)]. Alekseenko N.A., ed. XII Mezhdunarodnyy Vizantiyskiy seminar "Chersōnos themata: 'imperiya' $i$ 'polis"'. Materialy nauchnoy konferentsii [The $12^{\text {th }}$ International Byzantine Seminar "Chersōnos themata: 'empire' and "polis",. Materials of scientifical conference]. Simferopol, Kolorit Publ., 2020, pp. 91-98.

24. Dushenko A.A. Metallicheskie zerkala iz raskopok Mangupskogo knyazheskogo dvortsa [Metal Mirrors from the excavations of the Prince's Palace of Mangup]. Zinko V.N., Zinko E.A., eds. XXI Bosporskie chteniya "Bospor Kimmeriyskiy $i$ varvarskiy mir v period antichnosti i srednevekovya. Obekty iskusstva v arkheologicheskom kontekste". Materialy mezhdunarodnoy nauchnoy konferentsii [The $21^{\text {st }}$ Bosporan Readings. Cimmerian Bosporus and the World of Barbarians in Antiquity and the Middle Ages. Objects of Art in an Archaeological Context: materials of International Scholarly Conference]. Simferopol, Kerch, NIC IAK KFU, IAK RAN, CAI BF "Demetra" Publ., 2020, pp. 101-109.

25. Zalesskaya V.N. Klad iz Ay-Vasilya: ob istoriko-kulturnykh svyazyakh srednevekovoy Yality [Treasure from Ai-Vasil: about the historical and cultural ties of medieval Yalta]. Antichnaya drevnost $i$ srednie veka [Antiquities and the Middle Ages], 1995, vol. 27: Vizantiya i srednevekovyy Krym [Byzantium and the medieval Crimea], pp. 98-101.

26. Karpov S.P. Regesty dokumentov Fonda Diversorum Filze Sekretnogo Arkhiva Genui, otnosyashchiesya $\mathrm{k}$ istorii Prichernomorya [Regests of documents of the Diversorum Filze Foundation of the Secret Archive of Genoa related to the history of the Black Sea region]. Prichernomore v srednie veka [The Black Sea region in the Middle Ages]. St. Petersburg, Aletheia Publ., 1998, vol. 3, pp.9-81.

27. Karpov S.P. Istoriya Trapezundskoy imperii [The History of the Empire of Trebizond]. St. Petersburg, Aletheia Publ., 2007. 624 p.

28. Karpov S.P. Vera i tserkov v Genuezskoy Gazarii [The Faith and the Church in Genoese Gazaria].
Yurasov A.V., ed. Istoriya Kryma. [The History of the Crimea]. In 2 vols. Vol. 1. Moscow, Kuchkovo pole Publ., 2019, pp. 353-355.

29. Kashovskaya N.V. K itogam izucheniya karaimskogo nekropolya $\mathrm{v}$ ushchele Tabana-dere (Mangup): problemy khronologii i periodizatsii [On the Results of the Study of the Karaite Cemetery in TabanaDere Ravine: the aspects of Chronology and Periodization]. Materialy po arkheologii, istorii $i$ etnografii Tavrii [Materials in Archaeology, History and Ethnography of Tauria], 2017, vol. 22, pp. 239-277.

30. Korzukhina G.F., Peskova A.A. Drevnerusskie enkolpiony. Kresty-relikvarii XI-XIII vv. [Ancient Rus' Encolpions. Reliquary Crosses of the $11^{\text {th }}-13^{\text {th }}$ centuries]. St. Petersburg, Peterburgskoe vostokovedenie Publ., 2003.432 p.

31. Kramarovskiy M.G. Latinskaya Romaniya i zolotoordynskiy Krym. Latinskie perstnevye nakhodki i pechati v Severnom Prichernomore. Klad iz Ay-Vasil [Latin Romania and the Golden Horde's Crimea. The Finds of Latin Finger-Rings and the Seals in the Northern Black Sea Region. The Treasure from Ai-Vasil]. Evglevskiy A.V., ed. Stepi Evropy v epokhu srednevekovya. Vol. I [The European Stepps in the Middle Ages]. Donetsk, DonGU Publ., 2000, pp. 245-263.

32. Kramarovskiy M.G. Persten s rodovym gerbom semi Spinola, naydennyy na Mangupe [Ring with the ancestral coat of arms of the Spinola family, found on Mangup]. Antichnaya drevnost i srednie veka [Antiquities and the Middle Ages], 2001, vol. 32, pp. 376-386.

33. Leper R.H. Soobshchenie o raskopkakh na Mangupe v $1913 \mathrm{~g}$. [Report on the excavations at Mangup in 1913]. Izvestiya Tavricheskoy Uchenoy Arhivnoy komissii [Proceedings of the Tavrichesky Academic Archive Commission], 1914, no. 51, pp. 297-300.

34. Maiko V.V. Vostochnyy Krym vo vtoroy polovine X-XII vv. [Eastern Crimea in the second half of the $10^{\text {th }}-12^{\text {th }}$ centuries]. Kiev, Vyd. Oleg Filyuk, 2014. $467 \mathrm{p}$.

35. Maiko V.V. Kompleks khristianskikh raritetov iz raskopok khrama u podnozhiya gory Kilisa-Kaya bliz Sudaka [An Assemblage of Christian Rarities Excavated from the Church at the Foot of Kilisa-Kaia Mountain in Vicinity of Sudak]. Alekseenko N.A., ed. Chersōnos themata [Chersōnos themata]. Vol. 2: Miry Vizantii: sbornik nauchnykh trudov [Worlds of Byzantium: collection of scientific proceedings]. Simferopol, IAK RAN Publ., 2019, pp. 103-114.

36. Myts V.L. Kaffa i Feodoro v XV v. Kontakty i konflikty [Caffa and Theodoro in the $15^{\text {th }}$ century. Contacts and conflicts]. Simferopol, Universum Publ., 2009. 528 p.

37. Yashaeva T., Denisova E., Ginkut N., Zalesskaya V., Zhuravlev D. Nasledie vizantiyskogo Khersona [The Legacy of Byzantine Cherson]. 
Sevastopol, Teleskop Publ.; Ostin, Institut klassicheskoy arkheologii Publ., 2011. 708 p.

38. Naumenko V.E., Dushenko A.A. Knyazheskiy dvorets Mangupskogo gorodishcha: pomeshchenie $\mathrm{H}$ yuzhnogo uchastka kompleksa (po materialam kollektsii R.H. Lepera Gosudarstvennogo Ermitazha i sovremennykh arkheologicheskikh issledovaniy [Prince's Palace in Ancient Mangup: Room H in the Southern Area of the Complex (According to the Materials of R.Kh. Leper's Collections in the State Hermitage Museum and Recent Archaeological Researches]. Materialy po arkheologii, istorii $i$ etnografii Tavrii [Materials in Archaeology, History and Ethnography of Tauria], 2017, vol. XXII, pp. 187-238.

39. Makarov N.A., Greshnikov E.A., Zaytseva I.E., Podurets K.M., Kovalenko E.S., Murashev M.M. Nevidimye svyatyni. Vlozheniya v srednevekovykh krestakh-enkolpionakh po dannym kompleksnykh analiticheskikh issledovaniy [Invisible Holy Relics. Relics and Materials inserted in Medieval Reliquary Crosses based on the Data from comprehensive analytical studies]. Kratkie soobshcheniya Instituta arkheologii [Brief Communications of the Institute of Archaeology], 2020, vol. 258, pp. 25-45.

40. Peskova A.A. Traditsiya izobrazheniya svyatykh na vizantiyskikh krestakh-relikvariyakh [Traditional Images of Saints on Byzantine Reliquary Crosses]. Belyaev L.A., ed. Archeologia Abrahamica: Issledovaniya voblasti arkheologii i hudozhestvennoy traditsii iudaizma, khristianstva i islama [Archeologia Abrahamica: Studies in Archaeology and Artistic tradition of Judaism, Christianity and Islam]. Moscow, Indrik Publ., 2009, pp. 285-312.

41. Stepanenko V.P. Vladeteli Feodoro i vizantiyskaya aristokratiya XV v. [The Princes of Theodore and the Byzantine aristocracy of the $15^{\text {th }}$ century]. Antichnaya drevnost $i$ srednie veka [Antiquities and the MiddleAges], 2001, vol. 32, pp. 335-353.

42. Trepavlov V.V. Bolshaya Orda [A Large Horde]. Mirgaleev I., ed. Istoriya tatar s drevneyshikh vremen [History of the Tatars since ancient times]. In 7 vols. Vol. 4: Tatarskie gosudarstva XV-XVIII vv. [Tatar States of the $15^{\text {th }}-18^{\text {th }} \mathrm{cc}$.]. Kazan, Institut istorii im. SH. Mardzhani Publ., 2014, pp. 180-196.

43. Turova N.P. Srednevekovyy peshchernyy kompleks khrebta Iograf nad g. Yalta [Medieval cave complex of the Iograf ridge above Yalta]. Materialy po arkheologii i istorii antichnogo $i$ srednevekovogo Kryma [Materials on archeology and history of ancient and medieval Crimea], 2014, vol. 6, pp. 93-173.

44. Hautala R. Pismo Ladislava, frantsiskanskogo kustodiya Gazarii (Kaffa, 10 aprelya 1287 g.) [A Letter of Ladizlaus, the Franciscan Custodian of Gazaria (Caffa, April, 10, 1287)]. Zolotoordynskoe obozrenie [Golden Horde Review], 2017, vol. 5, no. 1, pp. 193-199.

45. Hautala R. Frantsiskantsy i dominikantsy v Zolotoy Orde. Razvitie missionerskoy deyatelnosti do serediny XIV v. [The Franciscans and Dominicans in the Golden Horde: the Development of Missionary Activity until the mid-fourteenth century]. Zolotoordynskoe nasledie: Materialy VIMezhdunarodnogo Zolotoordynskogo foruma "Pax Tatarica: genezis $i$ nasledie Zolotoy Ordy" [Golden Horde Legacy: Materials of the $6^{\text {th }}$ International Golden Horde Forum «Pax Tatarica: the Genesis and Legacy of the Golden Horde's Statehood»]. Kazan, Institut istorii im. SH. Mardzhani AN RT Publ., 2019, vol. 3, pp. 69-86.

46. Yashaeva T.Yu. Krest-enkolpion s vlozheniem iz Khersonesskoy baziliki 1935 g. [Reliquary Cross with an Enclosure from the «1935 Basilica» in Chersonesos]. Trudy Gosudarstvennogo Ermitazha. [Proceedings of the State Hermitage], 2017, vol. 89: Vizantiya v kontekste mirovoy kultury: materialy konferentsii, posvyashchennoy pamyati A.V. Bank (1906-1984) [Byzantium within the Context of the World Culture: materials of conference dedicated to the memory of A.V. Bank (1906-1984)], pp. 81-89.

47. Pitarakis B. Les croix-reliquaires pectorales Byzantines en bronze. Paris, Picard, 2006. 427 p.

48. Ryabtseva S. Pectoral reliquary-crosses from the Carpathian-Dniester region, $11^{\text {th }}-16^{\text {th }}$ centuries. Salamon M., Wołoszyn M., Musin A., Špehar P., eds. Rome, Constantinople and Newly-Converted Europe. Vol. II. Kraków; Leipzig, Geisteswissenschaftliches Zentrum Geschichte und Kultur Ostmitteleuropas; Warszawa, Instytut Archeologii i Etnologii Polskiej Akademii Nauk; Rzeszów, Instytut Archeologii Uniwersytetu Rzeszowskiego, 2012, pp. 527-543.

49. Vasiliev A.A. The Goths in the Crimea. Cambridge, Massachusetts, Mediaeval Academy of America, 1936. 292 p. 
B.E. Науменко. «Латиняне» на Мангупе. Уникальный западноевропейский крест-энколпион

\section{Information About the Author}

Valery E. Naumenko, Candidate of Sciences (History), Associate Professor, Department of Ancient and Middle Ages History, V.I. Vernadsky Crimean Federal University, Prosp. Vernadskogo, 4, 295007 Simferopol, Russian Federation, byzance@rambler.ru, https://orcid.org/0000-0002-2590-6314

\section{Информация об авторе}

Валерий Евгеньевич Науменко, кандидат исторических наук, доцент кафедры истории древнего мира и средних веков, Крымский федеральный университет им. В.И. Вернадского, просп. Вернадского, 4, 295007 г. Симферополь, Российская Федерация, byzance@rambler.ru, https://orcid.org/0000-0002-2590-6314 